\title{
Malvidin Protects against and Repairs Peptic Ulcers in Mice by Alleviating Oxidative Stress and Inflammation
}

\author{
Felipe Leonardo Fagundes (D), Quélita Cristina Pereira, Melina Luzzi Zarricueta and Raquel de Cássia dos Santos *D \\ Laboratory of Pharmacology and Molecular Biology, Post Graduate Program in Health Sciences, Medical School, \\ São Francisco University, Bragança Paulista, São Paulo 12916-900, Brazil; felipel_fagundes@hotmail.com (F.L.F.); \\ quelitapereirapa@gmail.com (Q.C.P.); melina.luzzi@hotmail.com (M.L.Z.) \\ * Correspondence: raquel.c.santos@gmail.com
}

Citation: Fagundes, F.L.; Pereira, Q.C.; Zarricueta, M.L.; dos Santos, R.d.C. Malvidin Protects against and Repairs Peptic Ulcers in Mice by Alleviating Oxidative Stress and Inflammation. Nutrients 2021, 13, 3312. https://doi.org/10.3390/ nu13103312

Academic Editor: Antoni Pons

Received: 25 August 2021

Accepted: 8 September 2021

Published: 23 September 2021

Publisher's Note: MDPI stays neutral with regard to jurisdictional claims in published maps and institutional affiliations.

Copyright: (c) 2021 by the authors. Licensee MDPI, Basel, Switzerland. This article is an open access article distributed under the terms and conditions of the Creative Commons Attribution (CC BY) license (https:/ / creativecommons.org/licenses/by/ $4.0 /)$.

\begin{abstract}
Peptic ulcer episodes cause damage to the stomach and intestine, with inflammatory cell infiltration and oxidative stress as the main players. In this study, we investigated the potential of anthocyanidin malvidin for preventive and curative peptic ulcer treatment. The anthocyanidin effects were examined in gastric ulcer mouse models induced by ethanol, non-steroidal anti-inflammatory drugs (NSAIDs), ischemia-reperfusion (IR), acetic acid and duodenal ulcer induced by polypharmacy. Expression levels of oxidative and inflammatory genes were measured to investigate the mechanism of anthocyanin activity. At a dose of $5 \mathrm{mg} \cdot \mathrm{kg}^{-1}$, Malvidin prevented gastric ulcer induction by ethanol, NSAID and repaired the tissue after 6 days of IR. Moreover, the anthocyanidin accelerated the healing of acetic acid-induced ulcer, increased the gene expression of EGF and COX-1, and downregulated MMP-9. Anthocyanin treatment mitigated the effect of polypharmacy on inflammation and oxidative stress observed in the intestine. Additionally, the compound downregulated cytokine expression and TLR4 and upregulated HMOX-1 and IL-10, exhibiting protective activity in the mouse gut. Malvidin thus prevented gastric and duodenal ulcers due to prominent anti-inflammatory and antioxidative effects on the gastrointestinal tract that were related to gene expression modulation and an increase in endogenous defense mechanisms.
\end{abstract}

Keywords: malvidin; peptic ulcer; mice; anti-inflammatory activity

\section{Introduction}

Peptic ulcer is the most common gastrointestinal disorder typically observed in the stomach or small intestine. Its estimated prevalence is $10-15 \%$ globally, but this range might underestimate the prevalence of duodenal lesions. The main etiological factor is Helicobacter pylori infection, but other factors, such as treatment with non-steroidal antiinflammatory drugs (NSAIDs), chronic stress, or alcohol consumption can trigger disease initiation [1]. Peptic ulcers are commonly treated with proton pump inhibitors (PPIs) or $\mathrm{H} 2$ blockers. The treatment limits chloride acid secretion, but it does not contribute to the healing phase. Moreover, continuous PPI use increases the risk of gastric adenocarcinoma and causes various severe side effects, including hepatotoxicity, headache, and in rare cases, Cushing syndrome [2]. Currently, PPIs are also associated with infection by Clostridium difficile and the development of pseudomembranous colitis [3]. Hence, the occurrence of severe adverse events limits the patient's quality of life; specifically, it results in treatment suspension and recurrence. The use of NSAIDs combined with other drugs to treat a wide range of diseases such as rheumatoid arthritis and myocardial infarction has resulted in a practice known as polypharmacy, which is common in older patients. Physicians typically manage the upper gastrointestinal side effects of NSAIDs with PPIs, but novel studies indicate that anti-inflammatory drugs combined with PPI can exacerbate the lesions in the small intestine [4].

Anthocyanidins are polyphenolic plant pigments found in fruits and vegetables. They typically have two or three substituents, including a sugar and frequently an organic acid 
group. According to the Nurse's Health Study II, the daily consumption of anthocyanidins is approximately $2-35 \mathrm{mg} \cdot \mathrm{kg}^{-1}$ in women [5]. A single serving of berries can supply 100-200 mg of anthocyanidins, which are 5-10-fold more abundant than other flavanols [6]. Malvidin is an anthocyanidin present in grapes, wine, and black rice in the glycoside and aglycone form [7]. Different pharmacological effects of Malvidin have been reported in the literature, including the prevention of cardiovascular diseases, cancer, and diabetes, along with anti-inflammatory and antioxidant activities [8-10]. However, their effects on gastric or duodenal ulcers have not been examined. In this study, we investigated the potential of Malvidin for the prevention and treatment of peptic ulcers in mouse models and characterized their mechanisms of action.

\section{Material and Methods}

\subsection{Chemical Compounds}

Malvidin hydrochloride ( $>98 \%$ purity) was obtained from Cayman Chemical Company (Ann Harbor, MI, USA; PubChem ID 69512). Lansoprazole and omeprazole were purchased from Medley Sanofi (Campinas, SP, Brazil; PubChem ID 3883 and 4594, respectively). Tri Reagent, HTAB (PubChem ID 5974), Alcian Blue (PubChem ID 129628421), acetyl salicylic acid (PubChem ID 2244), indomethacin (PubChem ID 3715), sodium carbonate (PubChem ID 10340), DMSO (PubChem ID 679), Purpald (PubChem ID 2723946), xanthine oxidase from microorganism, orto-dianisidine hydrochloride (PubChem ID 12309823), sodium hydroxide (PubChem ID 14798), potassium hydroxide (PubChem ID), potassium dihydrogen phosphate (PubChem ID 516951), sodium orthovanadate (PubChem ID 61671), sodium pyrophosphate (PubChem ID 24403), sodium fluoride (PubChem ID 5235), Triton X-100 (PubChem ID 5590), and reduced glutathione (PubChem ID 124886) were obtained from Sigma Aldrich (Saint Louis, MO, USA). Xylazine hydrochloride (PubChem ID 68554) and ketamine hydrochloride (PubChem ID 15851) were obtained from Sespo Industry (Paulínia, SP, Brazil). Potassium periodate (PubChem ID 516896), absolute ethanol (PubChem ID 702), hydrogen peroxide (PubChem ID 784), and acetic acid (PubChem ID 176) were from Synth Chemistry (São Paulo, SP, Brazil). Methanol (PubChem ID 887) and hydrochloric acid (PubChem ID 313) were acquired from J.T Backer (Xalostoc, Mexico). Hypoxanthine (PubChem ID 135398638), nitrobluetetrazolium (PubChem ID 9281), and DTNB (PubChem ID 6254) were obtained from Alfa Aesar (Tewksbury, MA, USA). EDTA (PubChem ID 6049), Tris (PubChem ID 6503), protease inhibitor cocktail, bovine serum albumin, and catalase from bovine liver were obtained from Thermo Fischer Scientific (Amherst, MA, USA). Celecoxib (PubChem ID 2662) was acquired from Tocris Bioscience (Bristol, UK). PMSF (PubChem ID 4784) was from Amresco company (Solon, OH, USA), and sodium dodecyl sulfate (PubChem ID 3423265) was purchased from Merck (Darmstadt, Germany).

\subsection{Animals}

Animal studies were conducted following the ARRIVE GUIDELINES. Male Swiss mice (Mus musculus) were provided by the Multidisciplinary Center for Biological Investigation in the Area of Laboratory Animals (Unicamp, SP, Brazil) after approval by the Ethics Committee in Animal Use of São Francisco University (protocol number 001.12.2017). The animals were maintained in standard conditions (12 h light/dark cycle and room temperature of $22 \pm 2{ }^{\circ} \mathrm{C}$ ), fed with Presence diet and with free access to water. All the experiments were conducted according to international and Brazilian standards of animal welfare. The animals were randomly divided in groups for all experiments. The dose chosen for the positive control was based on the experiments in previous results obtained by our group an in the references in the literature [11]. 


\subsection{Gastric Ulcer Induced by Absolute Ethanol}

The mice were divided in four experimental groups including naïve, vehicle (saline solution $\mathrm{NaCl} 0.9 \%$ ), positive control (Lansoprazole $30 \mathrm{mg} \cdot \mathrm{kg}^{-1}$, a proton pump inhibitor that blocks gastric lesion), and Malvidin $\left(5 \mathrm{mg} \cdot \mathrm{kg}^{-1}\right)$, based in previous experiments done by our group (unpublished data) $n=5$. The drugs were administered by oral gavage one hour before giving absolute ethanol $(0.2 \mathrm{~mL} /$ animal). Sixty minutes later, the animals were euthanized by administration of xylazine and ketamine $(1: 1 \mathrm{v}, \mathrm{v})$ and the stomachs were collected for analyses of macroscopic lesion area using Av Soft Bio View Spectra (Paulínia, SP, Brazil) and oxidative and inflammatory parameters [12].

\subsection{Gastric Ulcer Induced by Non-Steroidal Anti-Inflammatory Drug}

The mice were divided into four different groups including vehicle (saline solution $\mathrm{NaCl} 0.9 \%$ ), positive control (Lansoprazole $30 \mathrm{mg} \cdot \mathrm{kg}^{-1}$ ), test group (Malvidin $5 \mathrm{mg} \cdot \mathrm{kg}^{-1}$ ), or naïve (animals that did not receive any treatment) $n=5$. Briefly, fasted animals were pretreated with the control and the test compound by oral gavage $1 \mathrm{~h}$ prior to Indomethacin $\left(50 \mathrm{mg} \cdot \mathrm{kg}^{-1}\right)$ administration. Six and a half hours later, the mice were euthanized with xylazine and ketamine overdose $(1: 1 \mathrm{v}, \mathrm{v})$ and the stomachs were collected for macroscopic analyses of lesion area using Av Soft Bio View Spectra and to verify oxidative and inflammatory parameters [13-15].

\subsection{Gastric Ulcer Induced by Ischemia-Reperfusion}

The preventive model animals were divided into test (Malvidin $5 \mathrm{mg} \cdot \mathrm{kg}^{-1}$ ) positive control (Lansoprazole $30 \mathrm{mg} \cdot \mathrm{kg}^{-1}$ ), negative control (saline solution $\mathrm{NaCl} 0.9 \%$ ) and sham (only operated, but not received any treatment) $n=3$ and were submitted to the model of gastric injury induced by ischemia-reperfusion. Fasting mice were anesthetized with the combination of xylazine $\left(8 \mathrm{mg} \cdot \mathrm{kg}^{-1}\right)$ and ketamine $\left(80 \mathrm{mg} \cdot \mathrm{kg}^{-1}\right)$ and a laparotomy was made to access the left gastric artery. Then, a micro clamp was inserted, and the gastric circulation was interrupted for $30 \mathrm{~min}$. Subsequently, the clap was removed, and reperfusion occurred for one hour. Then, the animals were euthanized with a combination of xylazine hydrochloride and ketamine $(1: 1 \mathrm{v}, \mathrm{v})$ and the stomachs were collected to analyze macroscopic lesion area and verification of oxidative and inflammatory parameters [16-18]. In the curative model, the same surgical procedures were conducted, but the animals did not receive any pre-treatment, and $24 \mathrm{~h}$ after the surgery, they received oral administration of Malvidin $\left(5 \mathrm{mg} \cdot \mathrm{kg}^{-1}\right)$, Lansoprazole $\left(30 \mathrm{mg} \cdot \mathrm{kg}^{-1}\right)$, and Vehicle for 6 days $(n=5)$. Sham animals were included to validated the experiment. In the seventh day, the mice were euthanized, and the tissues were collected for macroscopic, inflammatory, and oxidative analyses. All the drugs used in these experiments were administered by oral gavage.

\subsection{Gastric Ulcer Induced by Acetic Acid}

The animals were divided into the naïve (did not receive any treatment), vehicle (saline solution $\mathrm{NaCl} 0.9 \%$ ), Lansoprazole $\left(30 \mathrm{mg} \cdot \mathrm{kg}^{-1}\right.$ ), and test (Malvidin $5 \mathrm{mg} \cdot \mathrm{kg}^{-1}$ ) groups $(n=7)$ and were submitted to the model of gastric ulcer induced by acetic acid. Briefly, fasted mice were anesthetized with a combination of xylazine hydrochloride $\left(8 \mathrm{mg} \cdot \mathrm{kg}^{-1}\right)$ and ketamine $\left(80 \mathrm{mg} \cdot \mathrm{kg}^{-1}\right)$ and the abdomen were opened to expose the stomach. In the serosal surface, a $4.2 \mathrm{~mm}$ micro tube was positioned and $20 \mu \mathrm{L}$ of acetic acid $80 \%(v / v)$ were placed in the tube for $35 \mathrm{~s}$. Subsequently, the organ was cleaned with heat saline solution $(\mathrm{NaCl} 0.9 \%)$ and the abdomen was closed. Twenty-four hours after the surgery, the oral treatment was initiated for 14 days. On the fifteenth day, the animals were euthanized using xylazine and ketamine $(1: 1 \mathrm{v}, \mathrm{v})$ and the ulcer region was collected to analyze the macroscopic lesion area, perform RT-PCR, and biochemical parameters [19-21]. 


\subsection{Duodenal Ulcer Induced by Polypharmacy}

Animals were divided into the naïve, test (Malvidin $5 \mathrm{mg} \cdot \mathrm{kg}^{-1}$ ), and vehicle (saline solution) groups $(n=7)$ and were submitted to the model of duodenal ulcer induced by polypharmacy. The mice received omeprazole $\left(20 \mathrm{mg} \cdot \mathrm{kg}^{-1}\right)$ daily and on the second day were administered with acetyl salicylic acid $\left(10 \mathrm{mg} \cdot \mathrm{kg}^{-1}\right)$. On the fifth day, the animals received Celecoxib (10 $\mathrm{mg} \cdot \mathrm{kg}^{-1}$ two times a day). On the ninth day, the animals received the intervention (Malvidin $5 \mathrm{mg} \cdot \mathrm{kg}^{-1}$ ). All drugs administered were by oral gavage. Five days after the beginning of treatment with the experimental compound, the mice were euthanized with a combination of xylazine and ketamine $(1: 1 \mathrm{v}, \mathrm{v})$, and samples of the duodenum were collected to determine inflammatory and oxidative parameters [22,23].

\subsection{Antioxidant and Inflammatory Parameters}

Samples of stomach and duodenum were homogenized in the extraction buffer to determine the levels of catalase (CAT), reduced glutathione (GSH), and superoxide dismutase (SOD). The tissue homogenate was centrifuged at $14,000 \mathrm{rpm}$ for $45 \mathrm{~min}$ and the supernatant was collected for enzymatic determination. Protein concentration was determined by biuret method using the Protal Kit (Laborclin, Minas Gerais, Brazil). For detailed protocols, consult the following work [24-26]. Myeloperoxidase was determined in $540 \mathrm{~nm}$ in the presence of hydrogen peroxide and o-dianisidine [27]. The results were expressed in units per gram of tissue similar to previously published works. Cytokine levels of tumor necrosis factor alpha (TNF- $\alpha$ ), interleukin 1 beta (IL-1 $\beta$ ), interleukin 6 (IL-6), and interleukin 10 (IL-10) were measured by enzyme-linked immunosorbent assay (ELISA) using mouse cytokines ELISA kits from R\&D Systems according to the manufacturer's protocol.

\subsection{Quantitative qPCR Analyses}

Stomach and duodenal strips, maintained in RNA later solution (Invitrogen, California, USA), were extracted using the Trizol Reagent. For RT-PCR, total RNA was reverse transcribed using the High-Capacity cDNA Reverse Transcription Kit (Applied Biosystems, Foster City, CA, USA). The synthesized cDNAs were amplified with Go Taq Q PCR Master Mix (Promega, Madison, WI, USA) and the reaction was performed using a 7300 Detection System. The relative amount of the target gene was calculated using the $-2^{\Delta \Delta C T}$ method with $\beta$-actin as a housekeeping gene. Primer pairs were designed based in the validated FASTA sequence using NCBI database and employing Primer3 software following the parameters: primer length $20-22$ bases, melting temperature $60{ }^{\circ} \mathrm{C}$, and amplicon size between 95 and 110 base-pair [28-30] (see in Table 1).

Table 1. Genes selected to characterize the mechanism of action of malvidin in gastric ulcer induced by acetic acid and duodenal ulcer induced by polypharmacy in mice.

\begin{tabular}{|c|c|c|}
\hline Gene & Sequence $5^{\prime}-3^{\prime}$ & GenBank Number \\
\hline$M M P-2$ & $\begin{array}{c}5^{\prime} \text {-GGACAGTGACACCACGTGAC-3' } \\
5^{\prime} \text {-TGACACAGCCTTCTCCTCCT-3' }\end{array}$ & 17,390 \\
\hline MMP-9 & $\begin{array}{l}\text { 5'-CGTCGTGATCCCCACTTACT-3' } \\
\text { 5'-AACACACAGGGTTTGCCTTC-3' }\end{array}$ & 17,395 \\
\hline CASP-3 & $\begin{array}{l}\text { 5'-GGCCGTGTTTCTGTTTTGTT-3' } \\
\text { 5'-TTGAGGTAGCTGCATGTGG-3' }^{\prime}\end{array}$ & 12,367 \\
\hline COX-1 & $\begin{array}{l}\text { 5'-AGGGTGTCTGTGTCCGCTTT-3' } \\
5^{\prime} \text {-GTTGGGGACTGGAGTCTTGC-3' }\end{array}$ & 19,224 \\
\hline COX-2 & $\begin{array}{l}5^{\prime} \text {-CCCCAAAGATAGCATCTGGA-3' } \\
5^{\prime} \text {-TGCAGAATTGAAAGCCCTCT-3 }\end{array}$ & 19,225 \\
\hline
\end{tabular}


Table 1. Cont.

\begin{tabular}{|c|c|c|}
\hline Gene & Sequence $5^{\prime}-3^{\prime}$ & GenBank Number \\
\hline \multirow[t]{2}{*}{$E G F$} & 5'-AGGCATCAAGCACGGTAGGT-3' & 13,645 \\
\hline & 5'-AGCAAGCACACCCCGTAAGT-3' & \\
\hline \multirow[t]{2}{*}{ iNOS } & 5'-TGGTGGTGACAAGCACATTT-3' & 18,126 \\
\hline & $5^{\prime}$-AAGGCCAAACACAGCATACC-3' & \\
\hline \multirow[t]{2}{*}{ B-actin } & $5^{\prime}$-ACGAGGCCCAGAGCAAGAG- $3^{\prime}$ & 11,461 \\
\hline & 5'-GGTGTGGTGCCAGATCTTCTC'-3' & \\
\hline \multirow[t]{2}{*}{$\mathrm{ZO}-1$} & 5'-CTGTGGGTTCCGTTTTGAGT-3' & 21,872 \\
\hline & $5^{\prime}$-CAGAAGGCCAAAGACTCCAG-3' & \\
\hline \multirow[t]{2}{*}{$C L N D$} & $5^{\prime}$-AAAATCCCTGACGGGGTATC-3' & 12,737 \\
\hline & 5'-GGCGTTTCTGGATGTTGTCT-3' & \\
\hline \multirow[t]{2}{*}{ OCLD } & $5^{\prime}$-CTCACGGAAACCAGAGAAGC-3' & 18,260 \\
\hline & 5'-GCATTTCTGGTGGACAAGGT-3' & \\
\hline \multirow[t]{2}{*}{$I L-1 \beta$} & 5'-CCCAAGCAATACCCAAAGAA-3' & 16,176 \\
\hline & 5'-TACCAGTTGGGGAACTCTGC-3' & \\
\hline \multirow[t]{2}{*}{$T N F-\alpha$} & $5^{\prime}$-TAGCCAGGAGGGAGAACAGA-3' & 21,926 \\
\hline & 5'-TTTCTGGAGGGAGATGTGG-3' & \\
\hline \multirow[t]{2}{*}{$I L-6$} & 5'-TCTCTGGGAAATCGTGGAA-3' & 16,193 \\
\hline & 5'-TTCTGCAAGTGCATCATCG-3' & \\
\hline \multirow[t]{2}{*}{ IL-10 } & 5'-AAAAGGTGCCACCCTGAAGA-3' & 16,153 \\
\hline & 5'-GATGTGGTGGGACCAACCTT-3' & \\
\hline \multirow[t]{2}{*}{ NRF2 } & $5^{\prime}$-CCCAGGGTTTGAAAAGTGAA-3' & 18,024 \\
\hline & 5'-GCTGGAAAGTGAAGGCAGTC-3' & \\
\hline \multirow[t]{2}{*}{ HMOX-1 } & $5^{\prime}$-CGATCTCAAGCAAGCCCTAC-3' & 15,368 \\
\hline & 5'-TTGGTGAGTTCCTCCTTGCT-3' & \\
\hline \multirow[t]{2}{*}{ TLR4 } & 5'-AGAAAATGCCAGGATGATGC-3' & 21,898 \\
\hline & $5^{\prime}$-AGGGATTCAAGCTTCCTGGT-3' & \\
\hline \multirow[t]{2}{*}{$P P A R-\gamma$} & 5'-CCCTGGTGTCCCAACTCTTA-3' & 19,016 \\
\hline & 5'-GTGCAACAGAAGAGCCATCA-3' & \\
\hline
\end{tabular}

Target genes, primer sequence and GenBank number used in the RT-PCR analyses.

\subsection{Statistical Analyses}

The Lilliefors normality test was applied to verify the data normality in all data sets. Results were expressed as mean \pm s.e.m and One Way Analyses of Variance (ANOVA) were applied to verify the difference between the means followed by the Dunnett's test or Student $\mathrm{T}$ test. Statistical analyses were performed using Graph Pad Prism 8.0 (San Diego, CA, USA). A $p$-value less than 0.05 was considered significant.

\section{Results}

3.1. Malvidin Protected the Gastric Mucosa from Lesions Induced by Absolute Ethanol and Ameliorated the Inflammatory Parameters in the Stomach

To examine the potential gastroprotective effects of Malvidin, we used a mouse model of acute gastric lesions induced by absolute ethanol. We observed that the compound could inhibit the induction of lesions with a dose of $5 \mathrm{mg} / \mathrm{kg}$ (Figure 1). The potential anti-inflammatory activity of Malvidin in the gastric tissue was tested using the myeloperoxidase (MPO) assay. We observed that Malvidin reduced the MPO activity at the same dose that promoted gastroprotection. The positive control lansoprazole also promoted a significant reduction in MPO activity compared to the vehicle treatment (51.83\%). To further examine the underlying mechanism involved in the gastroprotection promoted by Malvidin, we measured the activity of endogenous redox enzymes. We observed that anthocyanidin did not prevent the depletion of superoxide dismutase (SOD) and catalase compared with that of the vehicle treatment. Neither affected the reduced glutathione (GSH) level (see in Table 2). 


\subsection{Malvidin Exerts a Protective Effect in the Indomethacin-Induced Gastric Ulcer Model by Promoting a Reduction in Inflammatory and Oxidative Markers}

To investigate the effect of Malvidin in the presence of NSAIDs, we performed an experiment in mice with indomethacin-induced gastric ulcer. In this model, a dose of $5 \mathrm{mg} \cdot \mathrm{kg}^{-1}$ of the compound inhibited the formation of lesions when compared to the vehicle treatment groups (Figure 1). Similar results were obtained with lansoprazole using a dose of $30 \mathrm{mg} \cdot \mathrm{kg}^{-1}$. Pre-treatment with Malvidin reduced the neutrophil infiltration measured as the MPO activity in stomach samples (35.84\%). To investigate the involvement of oxidative markers in anthocyanidin-promoted gastroprotection, we measured the activity of antioxidant enzymes and levels of GSH. Malvidin did not elevated the activity of SOD and CAT, but increased the GSH levels (1.76-fold) compared with those in the vehicle-treated group. Lansoprazole did not significantly modulate the oxidative markers in the indomethacin-induced model compared with the vehicle-treated group (see Table 2).

\subsection{Malvidin Did Not Protect the Stomach from Macroscopic Alterations Induced by Ischaemia-Reperfusion, but Modulated Antioxidant Enzymes in Both Preventive and Curative Models}

Pre-treatment with anthocyanidin Malvidin did not exert a protective role in the stomach of mice subjected to the ischemia-reperfusion protocol. The compound increased the macroscopic lesion area in the treated mice compared with that in the vehicle group (Figure 1). Only the control group did not show any lesions. Oral anthocyanidin administration did not prevent the neutrophil infiltration in the gastric tissue compared with that of the vehicle treatment. However, Malvidin affected the redox status, increasing the activity of SOD $(4.14 \times)$ and CAT $(2.87 \times)$ and elevating the levels of GSH $(3.96 \times)$. The positive control lansoprazole did not substantially affect inflammatory and oxidative parameters compared with that of the vehicle treatment (see in Table 3). In the curative model, Malvidin did not reduce the macroscopic lesion area when compared with the vehicle treated group; however, it maintained the antioxidants enzymes elevated (see in Table 3). After 6 days of anthocyanidin treatment, we observed a decrease in the myeloperoxidase activity, showing a time dependent mechanism of Malvidin related to neutrophil infiltration.

3.4. Malvidin Accelerates Gastric Ulcer Healing in Mice with Acetic Acid-Induced Gastric Ulcer by Modulating the Expression Levels of EGF, COX-1, and MMP-9

Daily treatment for 14 days with anthocyanidin promoted the reduction in the lesion area, as measured with a digital pachymeter (see Figure 2). Malvidin was also found to reduce the ulcer scar to $36.24 \%$ compared with the vehicle-treated group which received saline for the same period. The positive control (lansoprazole, $30 \mathrm{mg} \cdot \mathrm{kg}^{-1}$ ) also reduced the scar area compared with the vehicle group. Treatment with anthocyanidins altered the gene expression of relevant targets involved in gastric healing. Malvidin elevated the expression of the EGF gene (2.6-fold), encoding epidermal growth factor, and COX-1 (5-fold), encoding cyclooxygenase-1, as compared to those in the vehicle-treated mice. However, Malvidin did not change the expression levels of matrix metalloproteinase 2 but reduced the relative expression of MMP-9 (99.7\%) (see Figure 3). 
3.5. Malvidin Improves Antioxidant Defense in the Gastric Mucosa of Mice with Acetic acid-Induced Gastric Ulcer

Over 14 days of anthocyanidin treatment, Malvidin elevated the SOD activity in the gastric mucosa compared with that in the vehicle-treated group (2.68-fold). Malvidin did not promote alterations in the glutathione levels or CAT activity. The positive control lansoprazole did not modulate any of the tested antioxidants, exhibiting no effect on oxidative defense. The elevated redox status due to anthocyanidin administration was superior to that observed in the sham animals, indicating a substantial improvement (see Table 4).

3.6. Anthocyanidins Ameliorate the Inflammatory Status and Oxidative Parameters in Mice with Polypharmacy-Induced Duodenal Ulcer

Anthocyanidin treatment for 5 days reduced the MPO activity in the duodenum of mice subjected to polypharmacy compared with that in vehicle-treated mice $(61.32 \%)$. Moreover, Malvidin elevated the CAT activity in intestine samples (1.86-fold) but did not change the other oxidative parameters (i.e., SOD and GSH). Additionally, we investigated the efficacy of anthocyanidin in inhibiting cytokine production in the mouse model of polypharmacy. NSAID and PPI treatment elevated the release of proinflammatory mediators from immune cells, but treatment with $5 \mathrm{mg} \cdot \mathrm{kg}^{-1}$ of Malvidin decreased the tissue content of two major inflammatory mediators, tumor necrosis factor $\alpha$ (TNF- $\alpha$ ) and interleukin 6 (IL-6) $(60.56 \%$ and $53.27 \%$, respectively). Malvidin did not affect interleukin $1 \beta$ (IL-1 $\beta$ ) and interleukin 10 (IL-10) expression (see Table 5).

3.7. Malvidin Does Not Prevent Expression Profile Changes in Tight Junction Factors in the Duodenum of Mice with Polypharmacy-Induced Duodenal Ulcer

RT-PCR of duodenum samples for tight junction genes revealed substantial expression level alterations in ZO-1, encoding zonula occludens-1, CLDN-1, encoding claudin-1, and OCLN, encoding occludin, in the vehicle-treated group. Treatment with anthocyanidin malvidin, in turn, did not elevate any tight junction proteins (see Figure 4).

3.8. Malvidin Downregulates Genes Related to Inflammation, Oxidative Stress, and Immune System Activation in the Polypharmacy-Induced Duodenal Ulcer Model

RT-PCR analyses of small intestine samples revealed that vehicle-treated animals exhibited high expression levels of the proinflammatory cytokine genes such as IL-6, and TNF- $\alpha$. Moreover, anti-inflammatory cytokine genes, such as IL-10, were downregulated. Malvidin reduced the relative expression of IL- $6(55.74 \%)$ and TNF- $\alpha(64.29 \%)$ in the duodenum and elevated the expression of IL-10 (6.92-fold), indicating a potent anti-inflammatory mechanism. Moreover, it elevated HMOX-1 (heme oxygenase 1) and reduced TLR4 (tolllike receptor 4) expression in the small intestine (see Figure 4). 
Table 2. The effect of treatment with malvidin in different models of gastric ulcer prevention in mice.

\begin{tabular}{|c|c|c|c|c|c|c|c|c|}
\hline $\begin{array}{c}\text { Experimental } \\
\text { Model }\end{array}$ & $\begin{array}{l}\text { Treatment } \\
\text { (p.o.) }\end{array}$ & $\begin{array}{c}\text { Dose } \\
(\mathrm{mg} / \mathrm{kg})\end{array}$ & $\begin{array}{l}\text { Ulcerative Lesion } \\
\qquad\left(\mathrm{mm}^{2}\right)\end{array}$ & $\begin{array}{l}\text { Gastric Lesion } \\
\text { Inhibition (\%) }\end{array}$ & $\begin{array}{c}\text { MPO } \\
\text { (Unit of MPO/g) }\end{array}$ & $\underset{(\mathrm{nmol} / \mathrm{g})}{\mathrm{GSH}}$ & $\begin{array}{c}\text { CAT } \\
\text { (Unit of CAT/g) }\end{array}$ & $\begin{array}{c}\text { SOD } \\
\text { (Unit of SOD/g) }\end{array}$ \\
\hline \multirow{3}{*}{$\begin{array}{c}\text { Gastric ulcer } \\
\text { induced by } \\
\text { absolute ethanol }\end{array}$} & Vehicle & - & $243.0 \pm 68.0$ & - & $29.3 \pm 4.3$ & $827.3 \pm 85.1$ & $38.3 \pm 6.3$ & $16.6 \pm 3.0$ \\
\hline & Lansoprazole & 30 & $50.7 \pm 25.8$ & $79.1^{*}$ & $16.2 \pm 1.5^{*}$ & $962.2 \pm 153.2$ * & $61.1 \pm 6.1 *$ & $14.9 \pm 1.6$ \\
\hline & Naive & - & - & - & $16.8 \pm 1.6^{*}$ & $979.5 \pm 79.1^{* *}$ & $87.9 \pm 5.0^{* *}$ & $19.3 \pm 1.9^{*}$ \\
\hline \multirow{4}{*}{$\begin{array}{l}\text { Gastric ulcer } \\
\text { induced by } \\
\text { NSAID }\end{array}$} & Vehicle & - & $27.1 \pm 4.8$ & - & $20.7 \pm 2.0$ & $99.2 \pm 10.4$ & $36.8 \pm 4.5$ & $10.3 \pm 1.2$ \\
\hline & Lansoprazole & 30 & $1.7 \pm 0.6$ & $93.7^{* * * *}$ & $15.2 \pm 0.9^{*}$ & $122.2 \pm 12.3$ & $44.3 \pm 5.7$ & $13.3 \pm 2.7$ \\
\hline & Malvidin & 5 & $9.8 \pm 3.3$ & $63.8^{* *}$ & $13.3 \pm 1.0 *$ & $174.6 \pm 5.8^{* *}$ & $50.8 \pm 2.2$ & $16.2 \pm 1.6$ \\
\hline & Naive & & - & - & $10.4 \pm 0.7^{* *}$ & $142.0 \pm 13.1$ * & $56.6 \pm 6.9^{*}$ & $13.5 \pm 1.1$ \\
\hline
\end{tabular}

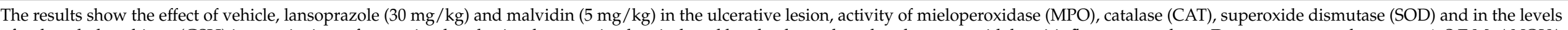

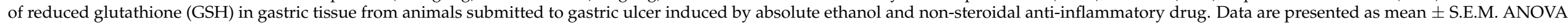
followed by Dunnett's test. ${ }^{*} p<0.05,{ }^{* *} p<0.01$ and ${ }^{* * *} p<0.0001$ represents difference in relation to control group treated with vehicle.

Table 3. Comparative analysis of malvidin activity in ischemia-reperfusion induced ulcers.

\begin{tabular}{|c|c|c|c|c|c|c|c|c|}
\hline $\begin{array}{l}\text { Experimental Model } \\
\text { Ischemia/Reperfusion }\end{array}$ & $\begin{array}{l}\text { Treatment } \\
\text { (p.o.) }\end{array}$ & $\begin{array}{c}\text { Dose } \\
(\mathrm{mg} / \mathrm{kg})\end{array}$ & $\begin{array}{l}\text { Ulcerative Lesion } \\
\left(\mathrm{mm}^{2}\right)\end{array}$ & $\begin{array}{l}\text { Gastric Lesion } \\
\text { Inhibition (\%) }\end{array}$ & $\begin{array}{c}\text { MPO } \\
\text { (Unit of MPO/g) }\end{array}$ & $\underset{(\mathrm{nmol} / \mathrm{g})}{\mathrm{GSH}}$ & $\begin{array}{c}\text { CAT } \\
\text { (Unit of CAT/g) }\end{array}$ & $\begin{array}{c}\text { SOD } \\
\text { (Unit of SOD/g) }\end{array}$ \\
\hline \multirow{3}{*}{ Preventive treatment } & Vehicle & - & $30.3 \pm 6.2$ & - & $16.3 \pm 1.4$ & $58.4 \pm 7.5$ & $18.2 \pm 3.3$ & $3.4 \pm 0.2$ \\
\hline & Lansoprazole & 30 & $2.4 \pm 1.4$ & $92.1 *$ & $13.4 \pm 1.6$ & $32.4 \pm 7.2$ & $7.5 \pm 0.4$ & $2.5 \pm 0.6$ \\
\hline & Naive & - & - & - & $12.2 \pm 0.2$ & $231.8 \pm 73.1^{*}$ & $29.8 \pm 7.2^{* * *}$ & $14.5 \pm 2.8^{* * *}$ \\
\hline \multirow{4}{*}{$\begin{array}{l}6 \text { days of post-ischemia- } \\
\text { reperfusion } \\
\text { treatment }\end{array}$} & Vehicle & - & $5.93 \pm 0.025$ & - & $29.87 \pm 6.36$ & $48.05 \pm 20.55$ & $53.10 \pm 6.03$ & $11.64 \pm 0.69$ \\
\hline & Lansoprazole & 30 & $0.38 \pm 0.12$ & 99.94 & $17.08 \pm 2.65 *$ & $59.69 \pm 3.73$ & $55.25 \pm 7.97$ & $9.99 \pm 0.32$ \\
\hline & Malvidin & 5 & $19.23 \pm 4.10$ & - & $15.63 \pm 0.76^{*}$ & $95.65 \pm 12.58$ * & $109.7 \pm 12.96^{*}$ & $14.02 \pm 1.04$ \\
\hline & Sham & - & - & - & $11.95 \pm 1.17^{*}$ & $129.3 \pm 0.00 *$ & $63.71 \pm 12.93$ & $15.16 \pm 1.16^{*}$ \\
\hline
\end{tabular}

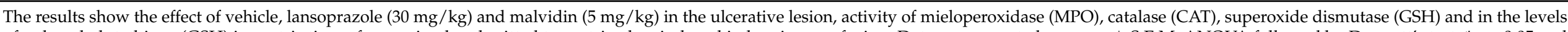

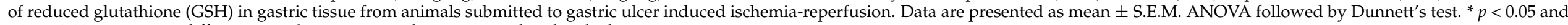
$* * * p<0.001$ represents difference in relation to control group treated with vehicle. 
Table 4. Effect of Malvidin treatment for 14 days after acetic acid-induced gastric ulcer.

\begin{tabular}{|c|c|c|c|c|c|c|c|}
\hline Experimental Model & $\begin{array}{l}\text { Treatment } \\
\text { (p.o.) }\end{array}$ & $\begin{array}{c}\text { Dose } \\
(\mathrm{mg} / \mathrm{kg})\end{array}$ & $\begin{array}{c}\text { Ulcerative Lesion } \\
\left(\mathrm{mm}^{2}\right)\end{array}$ & $\begin{array}{l}\text { Gastric Lesion } \\
\text { Reduction (\%) }\end{array}$ & $\begin{array}{c}\text { GSH } \\
(\mathrm{nmol} / \mathrm{g})\end{array}$ & $\begin{array}{c}\text { CAT } \\
\text { (Unit of CAT/g) }\end{array}$ & $\begin{array}{c}\text { SOD } \\
\text { (Unit of SOD/g) }\end{array}$ \\
\hline \multirow{3}{*}{$\begin{array}{l}\text { Acetic acid-induced } \\
\text { gastric ulcer }\end{array}$} & Vehicle & - & $7.1 \pm 0.6$ & - & $53.8 \pm 6.7$ & $26.7 \pm 3.8$ & $6.1 \pm 0.6$ \\
\hline & Lansoprazole & 30 & $4.8 \pm 0.5$ & $32.4 *$ & $72.05 \pm 13.2$ & $59.7 \pm 18.2$ & $7.2 \pm 1.6$ \\
\hline & Sham & - & - & - & $67.7 \pm 14.8$ & $33.2 \pm 2.9$ & $8.4 \pm 1.8$ \\
\hline
\end{tabular}

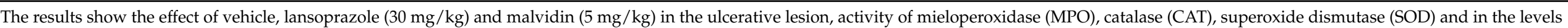

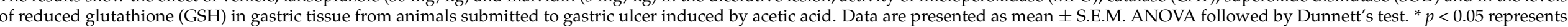
difference in relation to control group treated with vehicle.

Table 5. Effect of malvidin treatment in the polypharmacy-induced duodenal ulcer model.

\begin{tabular}{|c|c|c|c|c|c|c|c|c|c|c|}
\hline $\begin{array}{l}\text { Experimental } \\
\text { Model }\end{array}$ & $\begin{array}{l}\text { Treatment } \\
\text { (p.o.) }\end{array}$ & $\begin{array}{c}\text { Dose } \\
\text { (mg/kg) }\end{array}$ & $\begin{array}{c}\text { MPO } \\
\text { (Unit of } \\
\text { MPO/g) }\end{array}$ & $\begin{array}{c}\text { GSH } \\
(\mathrm{nmol} / \mathrm{g})\end{array}$ & $\begin{array}{c}\text { CAT } \\
\text { (Unit of } \\
\text { CAT/g) }\end{array}$ & $\begin{array}{c}\text { SOD } \\
\text { (Unit of } \\
\text { SOD/g) }\end{array}$ & $\begin{array}{c}\text { IL-10 } \\
(\mathrm{pg} / \mathrm{mL})\end{array}$ & $\begin{array}{c}\text { IL-6 } \\
\text { (pg/mL) }\end{array}$ & $\begin{array}{c}\text { IL-1 } \\
\text { (pg/mL) }\end{array}$ & $\begin{array}{c}\text { TNF- } \alpha \\
(\mathrm{pg} / \mathrm{mL})\end{array}$ \\
\hline \multirow{3}{*}{$\begin{array}{l}\text { Polypharmacy- } \\
\text { induced } \\
\text { duodenal }\end{array}$} & Vehicle & - & $95.3 \pm 19.4$ & $734.9 \pm 74.2$ & $45.6 \pm 6.0$ & $12.3 \pm 1.4$ & $1791.0 \pm 350.0$ & $495.8 \pm 167.7$ & $6377.0 \pm 1128.0$ & $1433.0 \pm 447.8$ \\
\hline & Malvidin & 5 & $36.9 \pm 8.0 * *$ & $765.0 \pm 66.4$ & $84.8 \pm 6.6^{* *}$ & $9.7 \pm 2.0$ & $1801.0 \pm 326.1$ & $193.2 \pm 40.8^{*}$ & $6056.0 \pm 861.2$ & $565.3 \pm 91.1 *$ \\
\hline & Naïve & - & $27.3 \pm 9.4^{* *}$ & $910.7 \pm 50.6$ & $84.0 \pm 4.1^{* *}$ & $16.7 \pm 0.5$ & $1799.0 \pm 494.7$ & $223.4 \pm 33.4$ & $5595.0 \pm 674.0$ & $649.6 \pm 112.6$ \\
\hline
\end{tabular}

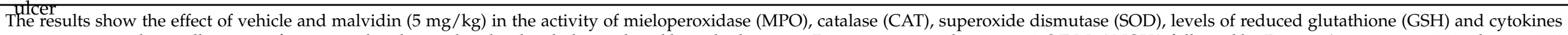

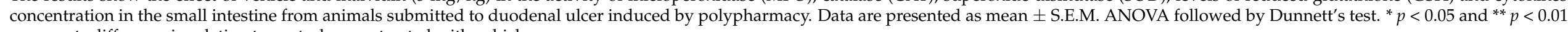
represents difference in relation to control group treated with vehicle. 


\begin{tabular}{|c|c|c|c|c|}
\hline Experimental Model & Vehicle & $\begin{array}{l}\text { Lansoprazole } \\
\left(30 \mathrm{mg} \cdot \mathrm{kg}^{-1}\right)\end{array}$ & $\begin{array}{l}\text { Malvidin } \\
\left(5 \mathrm{mg} \cdot \mathrm{kg}^{-1}\right)\end{array}$ & $\equiv$ \\
\hline Gastric ulcer induced by NSAID & & & & 无 \\
\hline $\begin{array}{l}\text { Gastric ulcer induced by ischemia-reperfusion } \\
\text { (preventive) }\end{array}$ & & & & 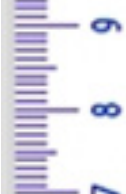 \\
\hline $\begin{array}{l}\text { Gastric ulcer induced by ischemia-reperfusion } \\
\text { (curative) }\end{array}$ & & & & 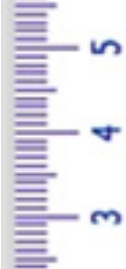 \\
\hline & & & & 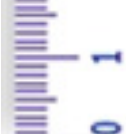 \\
\hline
\end{tabular}

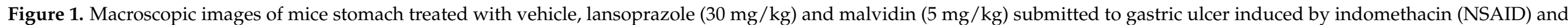
ischemia-reperfusion (both preventive and curative models). 


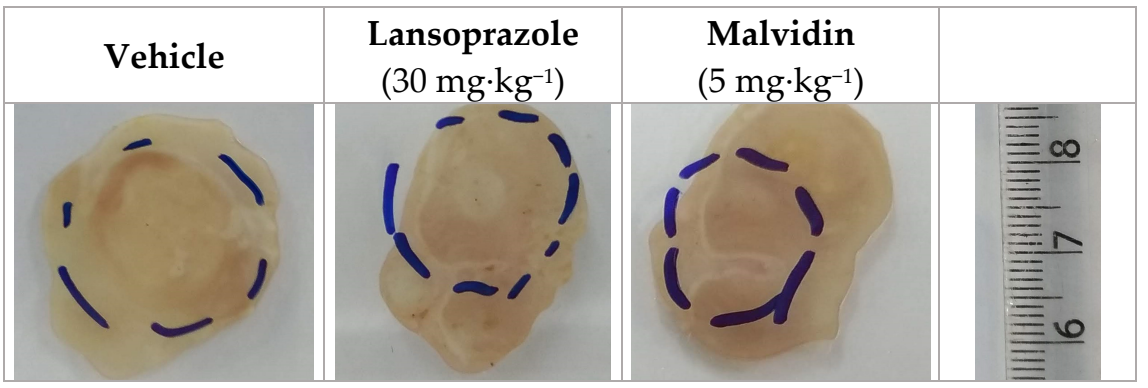

Figure 2. Macroscopic images of mice stomach submitted to gastric ulcer induced by acetic acid and treated for 14 days with vehicle, lansoprazole $(30 \mathrm{mg} / \mathrm{kg})$ and malvidin $(5 / \mathrm{mg} / \mathrm{kg})$. The dashed line represents the ulcer size and localization.

\section{A) MMP-2}

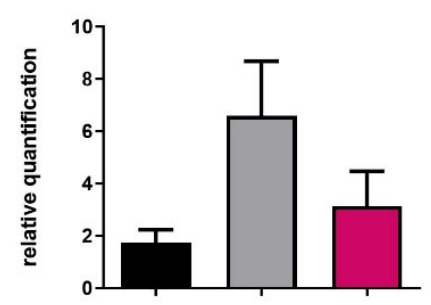

D) $\operatorname{COX}-2$

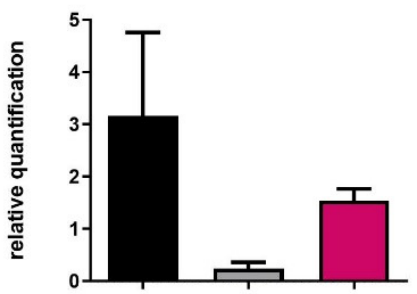

B) MMP-9

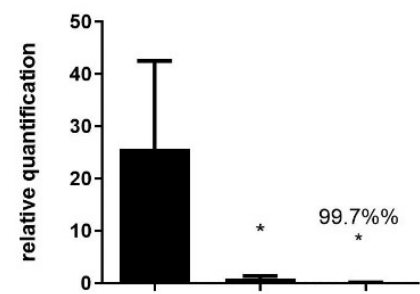

E) EGF

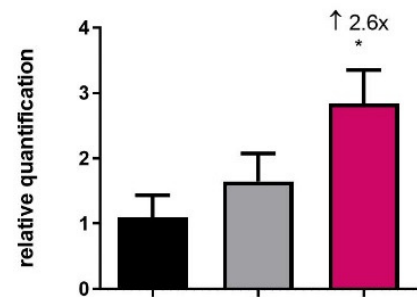

C) $\operatorname{cox}-1$

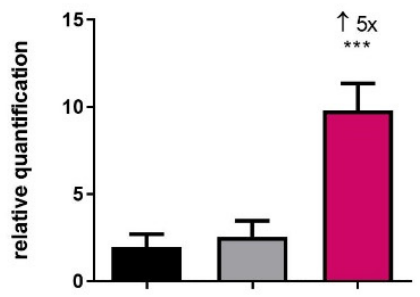

F) CASP-3

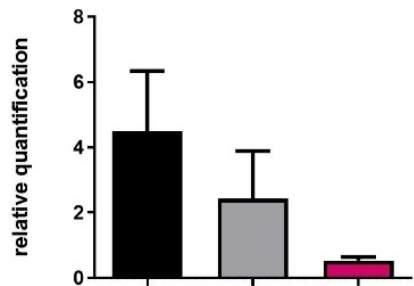

Vehicle $\square$ Lansoprazole (30 mg/kg)

Malvidin $(5 \mathrm{mg} / \mathrm{kg})$

Figure 3. (A) MMP-2, matrix metalloproteinase (B) MMP-9, matrix metalloproteinase (C) COX-1 cyclooxygenase 1 (D) COX2, cyclooxygenase 2 (E) EGF, epidermal growth factor and (F) CASP-3, caspase-3. The results show the relative gene expression of vehicle, lansoprazole $(30 \mathrm{mg} / \mathrm{kg})$ and malvidin $(5 \mathrm{mg} / \mathrm{kg})$ treated animals submitted to duodenal ulcer induced by polypharmacy. Data are presented as mean \pm S.E.M. ANOVA followed by Dunnett's test ${ }^{*} p<0.05{ }^{* * *} p<0.001$ represents difference in relation to control group treated with vehicle. 
A) MUC-3

B) ZO-1

C) CLDN-1

D) OCLN
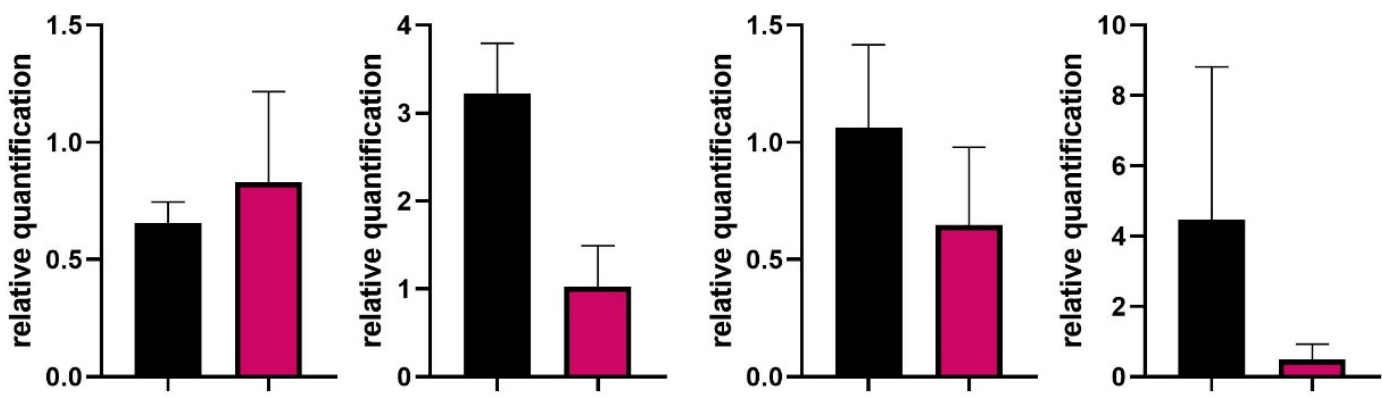

E) IL-1 $\beta$

F) IL-6

G) TNF- $\alpha$

H) IL-10
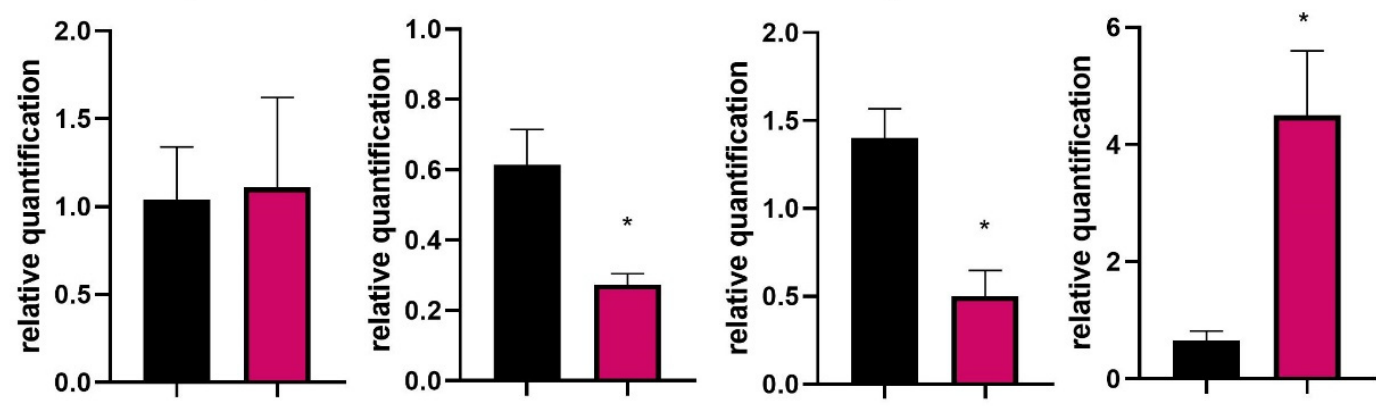

I) NRF2

J) PPAR- $\gamma$

K) TLR4

L) iNOS
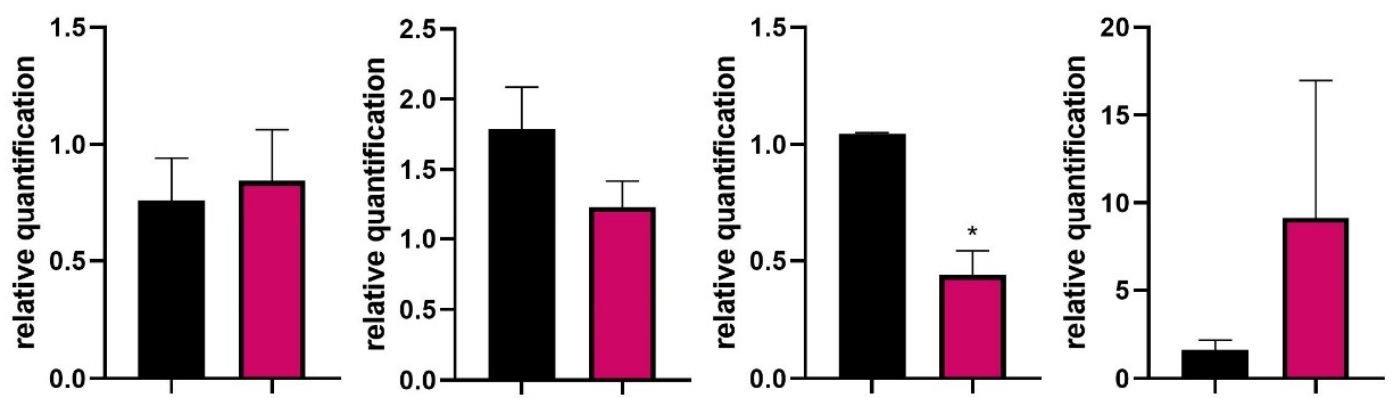

M) HMOX-1

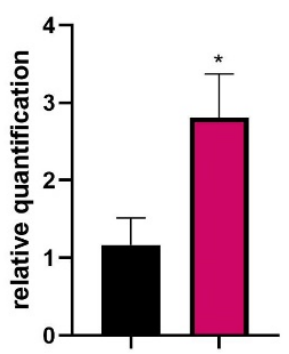

$$
\text { Vehicle } \square \text { Malvidin }(5 \mathrm{mg} / \mathrm{kg})
$$

Figure 4. (A) MUC-3, mucin 3 (B) ZO-1, zonula occludens 1 (C) CLDN-1, claudin 1 (D) OCLN, occludin (E) IL-1 $\beta$, interleukin 1 beta (F) IL-6, interleukin 6 (G) TNF- $\alpha$, tumor necrosis factor alfa (H) IL-10, interleukin 10 (I) NRF2, nuclear factor erythroid 2-related factor 2 (J) PPAR- $\gamma$, peroxisome proliferator-activated receptor gamma (K) TLR4, toll like receptor 4 (L) iNOS, inducible nitric oxide synthase (M) HMOX-1, heme oxygenase 1 . The results show the relative gene expression of vehicle or malvidin $(5 \mathrm{mg} / \mathrm{kg})$ treated animals submitted to duodenal ulcer induced by polypharmacy. Data are presented as mean \pm S.E.M. Parametric Student T Test ${ }^{*} p<0.05$ represents difference in relation to control group treated with vehicle. 


\section{Discussion}

The exposure of gastric mucosa to absolute ethanol is a classical experimental model of gastric ulcer used to determine the efficacy of lead compounds in the preventive treatment of peptic ulcer. The presence of alcohol causes a variety of cellular and oxidative damage, increases lipid peroxidation and production of leukotrienes, reduces glutathione content and sulfhydryl groups, and promotes neutrophil infiltration [31,32]. Anthocyanidin treatment inhibited the formation of macroscopic lesions in the gastric mucosa and reduced the inflammatory biomarker MPO. The myeloperoxidase activity represents one of the main indicators of gastric injuries [33], but it cannot elevate the activity of the main antioxidant enzymes catalase and superoxide dismutase. We believe that this dose was not sufficient to promote alterations in SOD activity based in the previous publish works, in which Malvidin was used in a dose 20 times higher [34]. Moreover, Malvidin did not elevate the levels of GSH, mainly because the compound could not activate the enzymes responsible for Glutathione synthesis in the cytoplasm of gastric cells.

We evaluated the response of the gastric mucosa to an anthocyanidin after induction with NSAID indomethacin. This gastric ulcer model is associated with excessive production of reactive oxygen species (ROS) during the ulceration process, leading to the oxidation of proteins and depletion of antioxidant defenses [35]. The production of ROS leads to lipid peroxidation, oxidation of intracellular proteins and nucleic acids, and the disruption of normal cell function [36]. Moreover, the presence of indomethacin elevates the release of proinflammatory mediators and promotes neutrophil infiltration [37]. In this model, Malvidin reduced the macroscopic lesion area, neutrophil influx, and increased the antioxidant defenses by blocking GSH depletion and elevating SOD activity. Published data showed similar effects of Malvidin found in the açai fruit [38].

To test the hypothesis that anthocyanidins are potent antioxidants in the gastrointestinal tract, we performed gastric ischemia-reperfusion in mice. Recent evidence showed that microvascular alterations and the generation of free radicals are the initiating events of mucosal injury induced by ischemia [39]. The ischemia process also induces cell death and mucosal injury that depends on the acute inflammatory response and oxidative damage [40]. In our study, Malvidin neither prevented the macroscopic lesions nor reversed the neutrophil infiltration in the preventive model. However, the compound increased the levels of selected antioxidant factors, confirming their protective role in the oxidative process. The scavenging activities of these compounds is not sufficient to prevent the inflammatory and oxidative consequences of ischemia-reperfusion in the gastric tissue [41]. At the end of the ischemic period, there is a return of both blood flow and oxygen level. However, the lower concentration of antioxidants in ischemic cells triggers an increase in the generation of local ROS, which results in oxidative stress, leading to endothelial dysfunction, DNA damage, and inflammatory response in the cascade at the site that could induce cell death $[39,42]$. As reported in the literature, the isolates of polyphenolic compounds cannot be used to treat oxidative disorders caused by inflammatory components. In the curative model, Malvidin exhibited the same behavior related to macroscopic lesion area; otherwise, the anthocyanidin treatment for six days reduced the neutrophil infiltrate measured by myeloperoxidase activity, showing a time dependent fashion in the gastric mucosa exposed to ischemia and reperfusion. These can be explained by the microvascular actions of anthocyanidins. In the absence of blood flow, the molecule cannot inhibit the leukocyte recruitment, which is related to the increase in lesion ratio and that it is regulated by inflammatory signals provided by immune cells in the lesion area. When the normal flow is restored, as observed in the curative model, there is a reduction in granulocyte presence, related to Malvidin treatment and probably a better bioavailability of the compound.

Our next experiment tested the healing potential of anthocyanidin in the gastric ulcer induced by acetic acid. This model closely mimics human ulcers and is useful for searching novel anti-ulcerogenic compounds [43]. The tested anthocyanidin increased tissue recovery after acetic acid exposure and downregulated genes related to matrix 
remodeling and inflammation and upregulated genes associated with cell growth. The chronic ulcers caused the elevation of matrix metallopeptidase-9, which is responsible for extracellular matrix degradation, indicating inflammation and ineffective healing $[44,45]$. Malvidin downregulated MMP-9 expression showing that anthocyanidin can control matrix degradation, contributing to ulcer healing. Other events observed during these processes are related to inflammation, which plays an important role in tissue repair. Anthocyanidin upregulated COX-1 expression, indicating selective activity affecting the cyclooxygenase enzymes that are crucial in the production of lipid mediators responsible for gastric maintenance and mucosal integrity, such as prostaglandin E2 [46,47]. Furthermore, this treatment also upregulated the EGF gene which promotes cell proliferation. As indicated in the literature, the EGF protein is critical for the proliferation and differentiation of gastric cells, as well as the regulation of glandular morphogenesis in the stomach [48]. During the healing process, there are alterations in the redox status of the gastric mucosa that are a consequence of immune cell infiltration and the release of ROS [49,50]. Malvidin could substantially restore the antioxidant defenses in gastric tissue by elevating SOD activity and GSH levels above baseline, indicating that these factors are fundamental in tissue repair.

The last model in our study was the duodenal ulcer induced by polypharmacy, which has physiopathological characteristics that differ from those observed in gastric ulcer. The presence of NSAIDs in the small intestine can cause alterations in the gut permeability and result in the production of specific lesions that are diagnosed through endoscopy [51,52]. The combination of selective NSAIDs with a PPI, which is used in clinics to prevent lesions in the stomach, is ineffective in preventing small intestinal injury, as demonstrated in clinical studies [53]. The combination of PPI, NSAIDs, and an anti-platelet aggregator, commonly used in patients with chronic pain and myocardial infarction, has been implicated in the pathophysiology of duodenal ulcer induced by polypharmacy [23]. NSAIDs disrupt the mucus barrier and change the commensal microbiota that protects the host from pathogenic organisms [54]. During the enteropathy caused by NSAIDs, we observed alterations in the expression of critical tight junction proteins, ZO-1, CLDN-1, and OCLN. These proteins regulate intestinal permeability and control the transit of substances, nutrients, bacteria, and toxins across the intestinal epithelia $[55,56]$. The anthocyanin treatment did not reverse the increased intestinal permeability observed in the vehicle group. The activation of TLR4 by bacterial lipopolysaccharide present in the gut lamina propria induces intracellular responses, such as the increase of the nuclear factor kappa B and induction of the transcription of inflammatory cytokines, including IL-6, IL-1 $\beta$, and TNF$\alpha$ [57]. The presence of Malvidin downregulated TLR4, demonstrating a protective role in the small intestine that is possibly related to a reduction in microbial sensing. Animals treated with the compound had lower expression levels of the proinflammatory cytokine TNF- $\alpha$ and IL-6, which are mainly secreted by macrophages and associated with a proinflammatory state. The presence of inflammatory cells also results in oxidative damage in the gut, which reduces antioxidant defenses. Nuclear erythroid factor 2-related factor 2 (NRF2) is a transcription factor associated with antioxidant enzymes, which plays a master role in redox homeostasis in the cells [58]. We observed that the administration of Malvidin did not change NRF2 expression levels, but increased CAT activity in the compound-treated groups, indicating that the NRF2 transcription factor is not a target of anthocyanin action. The elevated CAT activity is independent from NFR2 regulation and is not fully understood in the literature [59]. The administration of anthocyanidin also increased HMOX-1 expression, a key enzyme related to endogenous carbon monoxide release, which contributes to gastroprotection and is associated with the anthocyanin effects in the polypharmacy model $[60,61]$. 


\section{Conclusions}

Our study provided evidence for the pharmacological effects of Malvidin on peptic ulcer disease for the first time. This activity is associated with the reduction in inflammatory biomarkers, such as MPO, and an increase in endogenous antioxidant defenses, such as CAT, SOD, and GSH. Furthermore, it displayed preventive and healing capacity in the mouse models of gastrointestinal disorders. Treatment with absolute ethanol, indomethacin, and ischemia-reperfusion caused cellular and oxidative damage that Malvidin prevented by modulating redox system enzymes and inflammatory markers. In the acetic acid model, the compounds stimulated EGF and COX-1 gene expression and reduced MMP-9 expression, exhibiting target selectivity during the healing process. Additionally, anthocyanidins are novel therapeutic resources used to treat enteropathy induced by polypharmacy. Treatment with Malvidin improved the redox status in the small intestine and reduced the expression of proinflammatory genes, which is critical for maintaining the intestinal barrier and protecting the gut from microbial products. Based in these results and the general consumption of anthocyanidin by population, route of administration used in this study and the presence in fruits and foods, we recognize Malvidin as a promising molecule that can be used in the management of peptic ulcers by humans. Meanwhile, other studies are necessary to corroborate these findings.

Author Contributions: F.L.F., Q.C.P. and M.L.Z. performed most of the experiments, F.L.F. and R.d.C.d.S. contributed to the conception, design the study, and R.d.C.d.S. coordinated the study. All authors have read and agreed to the published version of the manuscript.

Funding: This work was financially supported by the Fundação de Amparo à Pesquisa do Estado de São Paulo [grant number 16/20600-0 from dos Santos, RC].

Institutional Review Board Statement: The study was conducted according to ARRIVE guideline, and approved by the Ethics Committee of São Francisco University (001.12.2017 approval in 1 March 2018).

Informed Consent Statement: Not applicable.

Data Availability Statement: The data presented in this study are available on request from the corresponding author.

Acknowledgments: We are grateful to Lúcio Fábio Caldas Ferraz from the São Francisco University and Marcelo Lima Ribeiro from Josep Carreras Leukemia Research Institute for discussions about RT-PCR analyses.

Conflicts of Interest: The authors declare no conflict of interest.

\section{References}

1. Lanas, A.; Chan, F.K. Peptic ulcer disease. Lancet 2017, 390, 613-624. [CrossRef]

2. Cheung, K.S.; Chan, E.W.; Wong, A.Y.; Chen, L.; Wong, I.C.; Leung, W.K. Long-term proton pump inhibitors and risk of gastric cancer development after treatment for Helicobacter pylori: A population-based study. Gut 2018, 67, 28-35. [CrossRef]

3. Trifan, A.; Stanciu, C.; Girleanu, I.; Stoica, O.C.; Singeap, A.M.; Maxim, R.; Chiriac, S.A.; Ciobica, A.; Boiculese, L. Proton pump inhibitors therapy and risk of Clostridium difficile infection: Systematic review and meta-analysis. World J. Gastroenterol. 2017, 23, 6500-6515. [CrossRef] [PubMed]

4. Wallace, J.L.; Syer, S.; Denou, E.; de Palma, G.; Vong, L.; McKnight, W.; Jury, J.; Bolla, M.; Bercik, P.; Collins, S.M.; et al. Proton pump inhibitors exacerbate NSAID-induced small intestinal injury by inducing dysbiosis. Gastroenterology 2011, 141, 1314-1322. [CrossRef] [PubMed]

5. Cassidy, A.; Mukamal, K.J.; Liu, L.; Franz, M.; Eliassen, A.H.; Rimm, E.B. High anthocyanin intake is associated with a reduced risk of myocardial infarction in young and middle-aged women. Circulation 2013, 127, 188-196. [CrossRef]

6. McGhie, T.K.; Ainge, G.D.; Barnett, L.E.; Cooney, J.M.; Jensen, D.J. Anthocyanin glycosides from berry fruit are absorbed and excreted unmetabolized by both humans and rats. J. Agric. Food Chem. 2003, 51, 4539-4548. [CrossRef] [PubMed]

7. Mazza, G. Anthocyanins in grapes and grape products. Crit. Rev. Food Sci. Nutr. 1995, 35, 341-371. [CrossRef]

8. Konczak, I.; Zhang, W. Anthocyanins-More Than Nature's Colours. J. Biomed. Biotechnol. 2004, 2004, 239-240. [CrossRef] [PubMed]

9. Wang, L.S.; Stoner, G.D. Anthocyanins and their role in cancer prevention. Cancer Lett. 2008, 269, 281-290. [CrossRef] [PubMed]

10. Grassi, D.; Desideri, G.; Ferri, C. Flavonoids: Antioxidants against atherosclerosis. Nutrients 2010, 2, 889-902. [CrossRef] 
11. Toma, W.; Hiruma-Lima, C.A.; Guerrero, R.O.; Souza Brito, A.R.M. Preliminary studies of Mammea americana L. (Guttiferae) bark/latex extract point to an effective antiulcer effect on gastric ulcer models in mice. Phytomedicine 2005, 12, 345-350. [CrossRef] [PubMed]

12. Robert, A.; Nezamis, J.; Lancaster, C.; Hanchar, A. Cytoprotection by prostaglandins in rats. Prevention of gastric necrosis produced by alcohol, $\mathrm{HCl}, \mathrm{NaOH}$, hypertonic $\mathrm{NaCl}$, and thermal injury. Gastroenterology 1979, 77, 433-443. [CrossRef]

13. Da Silva, D.M.; Martins, J.L.R.; de Oliveira, D.R.; Florentino, I.F.; da Silva, D.P.B.; dos Santos, F.C.A.; Costa, E.A. Effect of allantoin on experimentally induced gastric ulcers: Pathways of gastroprotection. Eur. J. Pharmacol. 2018, 821, 68-78. [CrossRef]

14. Guidobono, F.; Pagani, F.; Ticozzi, C.; Sibilia, V.; Pecile, A.; Netti, C. Protection by amylin of gastric erosions induced by indomethacin or ethanol in rats. Br. J. Pharmacol. 1997, 120, 581-586. [CrossRef]

15. Tamaddonfard, E.; Erfanparast, A.; Farshid, A.A.; Imani, M.; Mirzakhani, N.; Salighedar, R.; Tamaddonfard, S. Safranal, a constituent of saffron, exerts gastro-protective effects against indomethacin-induced gastric ulcer. Life Sci. 2019, $224,88-94$. [CrossRef]

16. Ueda, S.; Yoshikawa, T.; Takahashi, S.; Ichikawa, H.; Yasuda, M.; Oyamada, H.; Tanigawa, T.; Sugino, S.; Kondo, M. Role of free radicals and lipid peroxidation in gastric mucosal injury induced by ischemia-reperfusion in rats. Scand. J. Gastroenterol. 1989, 24 (Suppl. 162), 55-58. [CrossRef] [PubMed]

17. Brzozowski, T.; Konturek, P.C.; Konturek, S.J.; Drozdowicz, D.; Kwiecieñ, S.; Pajdo, R.; Bielanski, W.; Hahn, E.G. Role of gastric acid secretion in progression of acute gastric erosions induced by ischemia-reperfusion into gastric ulcers. Eur. J. Pharmacol. 2000, 398, 147-158. [CrossRef]

18. Ohara, R.; Périco, L.L.; Rodrigues, V.P.; Bueno, G.; Zanatta, A.C.; dos Santos, L.C.; Vilegas, W.; Constatino, F.B.; Justulin, L.A.; Hiruma-Lima, C.A.; et al. Terminalia catappa L. infusion accelerates the healing process of gastric ischemia-reperfusion injury in rats. J. Ethnopharmacol. 2020, 256, 112793. [CrossRef] [PubMed]

19. Okabe, S.; Roth, J.L.; Pfeiffer, C.J. A method for experimental, penetrating gastric and duodenal ulcers in rats. Observations on normal healing. Am. J. Dig. Dis. 1971, 16, 277-284. [CrossRef]

20. Arunachalam, K.; Damazo, A.S.; Pavan, E.; Oliveira, D.M.; de Freitas Figueiredo, F.; Machado, M.T.M.; Balogun, S.O.; Soares, I.M.; dos Santos Barbosa, R.; da Costa Alvim, T.; et al. Cochlospermum regium (Mart. ex Schrank) Pilg.: Evaluation of chemical profile, gastroprotective activity and mechanism of action of hydroethanolic extract of its xylopodium in acute and chronic experimental models. J. Ethnopharmacol. 2019, 233, 101-114. [CrossRef] [PubMed]

21. Magierowska, K.; Bakalarz, D.; Wójcik, D.; Chmura, A.; Hubalewska-Mazgaj, M.; Licholai, S.; Korbut, E.; Kwiecien, S.; Sliwowski, Z.; Ginter, G.; et al. Time-dependent course of gastric ulcer healing and molecular markers profile modulated by increased gastric mucosal content of carbon monoxide released from its pharmacological donor. Biochem. Pharmacol. 2019, 163, 71-83. [CrossRef] [PubMed]

22. Ferraris, R.P.; Vinnakota, R.R. The Time Course of Adaptation of Intestinal Nutrient Uptake in Mice Is Independent of Age. J. Nutr. 1995, 125, 2172-2182. [CrossRef]

23. Blackler, R.; Syer, S.; Bolla, M.; Ongini, E.; Wallace, J.L. Gastrointestinal-sparing effects of novel NSAIDs in rats with compromised mucosal defence. PLoS ONE 2012, 7, e35196. [CrossRef] [PubMed]

24. Winterbourn, C.C.; Hawkins, R.E.; Brian, M.; Carrell, R.W. The estimation of red cell superoxide dismutase activity. J. Lab. Clin. Med. 1975, 85, 337-341.

25. Aebi, H. Catalase in vitro. Methods Enzymol. 1984, 105, 121-126. [PubMed]

26. Faure, P.; Lafond, J.-L. Measurement of plasma sulfhydryl and carbonyl groups as a possible indicator of protein oxidation. In Analysis of Free Radicals in Biological Systems; Birkhäuser: Basel, Switzerland, 1995; pp. 237-248.

27. Krawisz, J.E.; Sharon, P.; Stenson, W.F. Quantitative assay for acute intestinal inflammation based on myeloperoxidase activity. Assessment of inflammation in rat and hamster models. Gastroenterology 1984, 87, 1344-1350. [CrossRef]

28. Livak, K.J.; Schmittgen, T.D. Analysis of relative gene expression data using real-time quantitative PCR and the $2^{-\Delta \Delta C T}$ method. Methods 2001, 25, 402-408. [CrossRef]

29. Gomes, A.É.I.; Stuchi, L.P.; Siqueira, N.M.G.; Henrique, J.B.; Vicentini, R.; Ribeiro, M.L.; Darrieux, M.; Ferraz, L.F.C. Selection and validation of reference genes for gene expression studies in Klebsiella pneumoniae using Reverse Transcription Quantitative real-time PCR. Sci. Rep. 2018, 8, 9001. [CrossRef] [PubMed]

30. Dos Santos, T.W.; Miranda, J.; Teixeira, L.; Aiastui, A.; Matheu, A.; Gambero, A.; Portillo, M.P.; Ribeiro, M.L. Yerba Mate Stimulates Mitochondrial Biogenesis and Thermogenesis in High-Fat-Diet-Induced Obese Mice. Mol. Nutr. Food. Res. 2018, 62, 1800142. [CrossRef]

31. Guslandi, M. Effects of ethanol on the gastric mucosa. Dig. Dis. 1987, 5, 21-32. [CrossRef] [PubMed]

32. Szabo, S.; Trier, J.S.; Brown, A.; Schnoor, J. Early vascular injury and increased vascular permeability in gastric mucosal injury caused by ethanol in the rat. Gastroenterology 1985, 88, 228-236. [CrossRef]

33. Wallace, J.L.; Ma, L. Inflammatory mediators in gastrointestinal defense and injury. Exp. Biol. Med. 2001, 226, 1003-1015. [CrossRef]

34. Wei, H.; Li, H.; Wan, S.P.; Zeng, Q.T.; Cheng, L.X.; Jiang, L.L.; Peng, Y.D. Cardioprotective effects of malvidin against isoproterenolinduced myocardial infarction in rats: A mechanistic study. Med. Sci. Monit. 2017, 23, 2007-2016. [CrossRef]

35. El-Ashmawy, N.E.; Khedr, E.G.; El-Bahrawy, H.A.; Selim, H.M. Nebivolol prevents indomethacin-induced gastric ulcer in rats. J. Immunotoxicol. 2016, 13, 580-589. [CrossRef] [PubMed] 
36. Ferrari, R.; Ceconi, C.; Curello, S.; Cargnoni, A.; Pasini, E.; Visioli, O. The occurrence of oxidative stress during reperfusion in experimental animals and men. Cardiovasc. Drugs Ther. 1991, 5 (Suppl. 2), 277-287. [CrossRef]

37. Cheng, Y.T.; Lu, C.C.; Yen, G.C. Phytochemicals enhance antioxidant enzyme expression to protect against NSAID-induced oxidative damage of the gastrointestinal mucosa. Mol. Nutr. Food Res. 2017, 61, 1600659. [CrossRef]

38. Petruk, G.; Illiano, A.; Del Giudice, R.; Raiola, A.; Amoresano, A.; Rigano, M.M.; Piccoli, R.; Monti, D.M. Malvidin and cyanidin derivatives from açai fruit (Euterpe oleracea Mart.) counteract UV-A-induced oxidative stress in immortalized fibroblasts. $J$. Photochem. Photobiol. B Biol. 2017, 172, 42-51. [CrossRef]

39. Wu, M.-Y.; Yiang, G.-T.; Liao, W.-T.; Tsai, A.P.-Y.; Cheng, Y.-L.; Cheng, P.-W.; Li, C.-Y.; Li, C.-J. Current Mechanistic Concepts in Ischemia and Reperfusion Injury. Cell. Physiol. Biochem. 2018, 46, 1650-1667. [CrossRef]

40. Hu, Y.; Tao, X.; Han, X.; Xu, L.; Yin, L.; Qi, Y.; Zhao, Y.; Xu, Y.; Wang, C.; Peng, J.; et al. Dioscin attenuates gastric ischemia/reperfusion injury through the down-regulation of PKC/ERK1/2 signaling via PKC $\alpha$ and PKC $\beta 2$ inhibition. Chem. Biol. Interact. 2016, 258, 234-244. [CrossRef] [PubMed]

41. Gesslbauer, B.; Bochkov, V. Biochemical targets of drugs mitigating oxidative stress via redox-independent mechanisms. Biochem. Soc. Trans. 2017, 45, 1225-1252. [CrossRef]

42. Ornellas, F.M.; Ornellas, D.S.; Martini, S.V.; Castiglione, R.C.; Ventura, G.M.; Rocco, P.R.; Gutfilen, B.; de Souza, S.A.; Takiya, C.M.; Morales, M.M.; et al. Bone marrow-derived mononuclear cell therapy accelerates renal ischemia-reperfusion injury recovery by modulating inflammatory, antioxidant and apoptotic related molecules. Cell. Physiol. Biochem. 2017, 41, 1736-1752. [CrossRef] [PubMed]

43. Okabe, S.; Amagase, K. An overview of acetic acid ulcer models-The history and state of the art of peptic ulcer research. Biol. Pharm. Bull. 2005, 28, 1321-1341. [CrossRef] [PubMed]

44. Ganguly, K.; Swarnakar, S. Chronic gastric ulceration causes matrix metalloproteinases-9 and -3 augmentation: Alleviation by melatonin. Biochimie 2012, 94, 2687-2698. [CrossRef] [PubMed]

45. Li, S.L.; Zhao, J.R.; Ren, X.Y.; Xie, J.P.; Ma, Q.Z.; Rong, Q.H. Increased expression of matrix metalloproteinase-9 associated with gastric ulcer recurrence. World J. Gastroenterol. 2013, 19, 4590-4595. [CrossRef]

46. Tarnawski, A.S. Cellular and molecular mechanisms of gastrointestinal ulcer healing. Dig. Dis. Sci. 2005, 50 (Suppl. 1), S24-S33. [CrossRef] [PubMed]

47. DeFoneska, A.; Kaunitz, J.D. Gastroduodenal mucosal defense. Curr. Opin. Gastroenterol. 2010, 26, 604-610. [CrossRef]

48. McCracken, K.W.; Catá, E.M.; Crawford, C.M.; Sinagoga, K.L.; Schumacher, M.; Rockich, B.E.; Tsai, Y.-H.; Mayhew, C.N.; Spence, J.R.; Zavros, Y.; et al. Modelling human development and disease in pluripotent stem-cell-derived gastric organoids. Nature 2014, 516, 400-404. [CrossRef] [PubMed]

49. Kwiecien, S.; Brzozowski, T.; Konturek, S.J. Effects of reactive oxygen species action on gastric mucosa in various models of mucosal injury. J. Physiol. Pharmacol. 2002, 53, 39-50.

50. Da Silva, L.M.; Pezzini, B.C.; Somensi, L.B.; Mariano, L.N.B.; Mariott, M.; Boeing, T.; dos Santos, A.C.; Longo, B.; Cechinel-Filho, V.; de Souza, P.; et al. Hesperidin, a citrus flavanone glycoside, accelerates the gastric healing process of acetic acid-induced ulcer in rats. Chem. Biol. Interact. 2019, 308, 45-50. [CrossRef]

51. Lanas, A.; Sopeña, F. Nonsteroidal Anti-Inflammatory Drugs and Lower Gastrointestinal Complications. Gastroenterol. Clin. N. Am. 2009, 38, 333-352. [CrossRef]

52. Syer, S.D.; Blackler, R.W.; Martin, R.; de Palma, G.; Rossi, L.; Verdu, E.; Bercik, P.; Surette, M.G.; Aucouturier, A.; Langella, P.; et al. NSAID enteropathy and bacteria: A complicated relationship. J. Gastroenterol. 2015, 50, 387-393. [CrossRef]

53. Goldstein, J.L.; Eisen, G.M.; Lewis, B.; Gralnek, I.M.; Zlotnick, S.; Fort, J.G. Video capsule endoscopy to prospectively assess small bowel injury with celecoxib, naproxen plus omeprazole, and placebo. Clin. Gastroenterol. Hepatol. 2005, 3, 133-141. [CrossRef]

54. Pavlidis, P.; Bjarnason, I. Aspirin Induced Adverse Effects on the Small and Large Intestine. Curr. Pharm. Des. 2015, 21, 5089-5093. [CrossRef] [PubMed]

55. Suzuki, T. Regulation of intestinal epithelial permeability by tight junctions. Cell. Mol. Life Sci. 2013, 70, 631-659.

56. De Medina, F.S.; Romero-Calvo, I.; Mascaraque, C.; Martínez-Augustin, O. Intestinal inflammation and mucosal barrier function. Inflamm. Bowel Dis. 2014, 20, 2394-2404. [CrossRef]

57. Kuzmich, N.N.; Sivak, K.V.; Chubarev, V.N.; Porozov, Y.B.; Savateeva-Lyubimova, T.N.; Peri, F. TLR4 signaling pathway modulators as potential therapeutics in inflammation and sepsis. Vaccines 2017, 5, 34. [CrossRef] [PubMed]

58. Sporn, M.B.; Liby, K.T. NRF2 and cancer: The Good, the bad and the importance of context. Nat. Rev. Cancer 2012, $12,564-571$. [CrossRef] [PubMed]

59. Glorieux, C.; Calderon, P.B. Catalase, a remarkable enzyme: Targeting the oldest antioxidant enzyme to find a new cancer treatment approach. Biol. Chem. 2017, 398, 1095-1108. [CrossRef]

60. Magierowska, K.; Magierowski, M.; Hubalewska-Mazgaj, M.; Adamski, J.; Surmiak, M.; Sliwowski, Z.; Kwiecien, S.; Brzozowski, T. Carbon monoxide (CO) released from tricarbonyldichlororuthenium (II) dimer (CORM-2) in gastroprotection against experimental ethanol-induced gastric damage. PLoS ONE 2015, 10, e0140493.

61. Magierowska, K.; Wojcik, D.; Chmura, A.; Bakalarz, D.; Wierdak, M.; Kwiecien, S.; Sliwowski, Z.; Brzozowski, T.; Magierowski, M. Alterations in Gastric Mucosal Expression of Calcitonin Gene-Related Peptides, Vanilloid Receptors, and Heme Oxygenase-1 Mediate Gastroprotective Action of Carbon Monoxide against Ethanol-Induced Gastric Mucosal Lesions. Int. J. Mol. Sci. 2018, 19, 2960. [CrossRef] 